\title{
Saber morir
}

Marcelo Casarin ${ }^{1}$

Por la proyección de sus acciones personales, y por la funciones públicas que desempeñó, se podría decir que fue un cordobés, un argentino, un latinoamericano, un ciudadano del mundo... aunque le gustaba reconocerse como un vecino del barrio Alberdi, donde nació y conoció el esplendor de la Cervecería Córdoba, del cine La Piojera y se apasionó con la suerte deportiva del club de sus amores, Belgrano.

También se reconocía parte de la Universidad Nacional de Córdoba, que le otorgó la máxima distinción para sus docentes: profesor emérito. No solo se recibió de abogado y se doctoró en esa casa de estudios, sino que fue su rector por dos periodos consecutivos, entre 1989 y 1995; y también de la UBA, en la recién recuperada democracia de 1983. Convencional constituyente por la provincia de Córdoba, en 1994, fue diputado nacional, director de la Biblioteca Nacional, Secretario de Educación de la Nación y Secretario de Cultura y Educación de la Ciudad de Córdoba; y fue secretario ejecutivo de CLACSO y presidente de FLACSO. Y en el umbral de los ochenta años seguía trabajando como director de un Posdoctorado y del Doctorado en Estudios Sociales de América Latina, dos programas radicados en una institución que él mismo creó, el Centro de Estudios Avanzados (UNC).

La tentación es seguir agregándole líneas al currículum, y me parece oír su voz diciéndome: evitemos los detalles, Marcelo. Disculpe maestro, pero no puedo dejar de mencionar algunos de sus libros: Crisis y protesta social (documento indispensable sobre el Cordobazo) y Tierra y conciencia campesina en Tucumán, ambos de 1970; Metáforas de la sociedad argentina, de 1987; La invención de la educación, de 1993; El desempleo de masas, de 1997; Señales, de 1999; La Crisis en la Crisis en 2002 y Repensar América Latina en 2004; y Memoria de la Sociología argentina, de 2013; 808 dias en la Universidad de Buenos Aires de 2014. Además, fue nombrado doctor hono-

\footnotetext{
${ }^{1}$ Coordinador del Posdoctorado del Centro de Estudios Avanzados de la Universidad Nacional de Córdoba (CEA-UNC).
} 
ris causa en las universidades de San Marcos (Perú, 1991), Nottingham (Inglaterra, 1993) y Soka (Tokio, Japón, 1994).

Cuál es el legado, cuál es la enseñanza de este hombre parco que me honró con su amistad y una manera pudorosa de evitar hablarme de su enfermedad, contra la que peleaba desde hacía un par de años; a pesar de su gravedad, la sobrellevó sin lloriqueos para que fuera menos evidente para nosotros y supiéramos que estaba luchando como quería: leyendo, escribiendo, dando clases, y siempre interponiendo su palabra pública en temas cruciales de la actualidad política del país y la región.

Y también me enseñó con algunos gestos (de los que nunca hizo alarde y de los supe por boca de alguno de sus beneficiarios): en los peores años de la historia reciente fue solidario sin condiciones con sus compatriotas, exiliados o perseguidos, y siempre estuvo dispuesto a darles una mano generosa.

Imaginé una despedida en la que estábamos varios de sus amigos (entre ellos, su maestro Alain Touraine; y también, anacrónicamente, Pancho Aricó) y cada uno a su turno le agradecía por algo; en cambio, había algunos jugadores y el propio técnico de Belgrano que no sé si le pedían disculpas o le recriminaban por irse así, sin darles tiempo para ganar una copa. Después, como si fuéramos un coro, le decíamos: hasta siempre Polaco.

(A la memoria de Francisco Delich [1937-2016]) 